\title{
PENGARUH PERSENTASE MALTODEKSTRIN DAN LAMA PENGERINGAN TERHADAP KANDUNGAN VITAMIN C MINUMAN SERBUK INSTAN TERONG CEPOKA (Solanum torvum)
}

\section{(Effect of Maltodextrin Concentration and Duration of Drying on Vitamin C Content of Instant Powdered Powder of Terong Cepoka (Solanum torvum)}

\author{
Karimatus Sakdiyah $^{1}$, Rekna Wahyuni ${ }^{2}$ \\ ${ }^{1}$ Mahasiswa Prodi Ilmu Teknologi Pangan Universitas Yudharta Pasuruan \\ ${ }^{2}$ Dosen Prodi Ilmu Teknologi Pangan Universitas Yudharta Pasuruan \\ *Penulis Korespodensi : karimatussakdiyah50001@gmail.com
}

\begin{abstract}
Cepoka eggplant (Solanum torvum) which has a bitter taste when consumed is less attractive to the public even though its properties are good for health. This study aims to determine the effect of maltodextrin percentage and drying time on vitamin $C$ content of instant powdered eggplant cepoka. The method used in the research of instant eggplant cepoka powder is Factorial Randomized Block Design (RBD) which consists of 2 factors: maltodextrin composition (10\%, 20\%, and 30\%) and drying time (6 hours and 7 hours). Each study was repeated 3 times so that 18 trials were obtained. Tests carried out include physicochemical (vitamin C test, water content test, soluble speed test) and organoleptic test (color, aroma, and taste). Data analysis is done by ANOVA. If it is significantly different, then it is continued by using the Smallest Significant Difference Test (BNT), organoleptic test using Friedman and to find the best treatment using the De Garmo Effectiveness Index (1984) method modified by Susrini (2003). The best results were found in the treatment of $30 \%$ maltodextrin and 7 hours drying time (M3P2) with the following results: KA (8.58\%), Soluble Speed $(0.34 \mathrm{~s})$, Vitamin $C(28.75 \mathrm{mg} / \mathrm{g})$, panelist's preference for 3.55 powder color (neutral / normal), 3 beverage color (neutral / normal), 2.65 (not liking) the drink aroma, and 2.85 (not like) the taste of the drink.
\end{abstract}

Keywords: maltodextrin, drying time, vitamin c, instant drink

\begin{abstract}
ABSTRAK
Terong cepoka (Solanum torvum) yang memiliki rasa pahit saat dikonsumsi kurang diminati oleh masyarakat walau pun khasiatnya yang baik bagi kesehatan. Penelitian ini bertujuan untuk mengetahui pengaruh persentase maltodekstrin dan lama pengeringan terhadap kandungan vitamin $\mathrm{C}$ minuman serbuk instan terong cepoka. Metode yang digunakan dalam penelitian serbuk instan terong cepoka yaitu Rancangan Acak Kelompok (RAK) Faktorial yang terdiri dari 2 faktor yaitu komposisi maltodekstrin $(10 \%, 20 \%$, dan $30 \%$ ) dan lama pengeringan (6 jam dan 7 jam). Masing-masing penelitian diulang sebanyak 3 kali sehingga diperoleh 18 kali percobaan. Uji yang dilakukan meliputi fisikokimia (uji vitamin $\mathrm{C}$, uji kadar air, uji kecepatan larut) dan uji organoleptik (warna, aroma, dan rasa). Analisa data dilakukan secara ANOVA. Jika berbeda nyata, maka dilanjutkan dengan menggunakan uji Beda Nyata Terkecil (BNT), uji organoleptik menggunakan Friedman dan untuk mencari perlakuan terbaik menggunakan metode Indeks Efektifitas De Garmo (1984) yang dimodifikasi oleh Susrini (2003). Hasil penelitian terbaik terdapat pada perlakuan persentase maltodekstrin 30\% dan lama pengeringan 7 jam (M3P2) dengan rincian hasil sebagai berikut: KA $(8,58 \%)$, Kecepatan Larut $(0,34 \mathrm{~s})$, Vitamin C $(28,75 \mathrm{mg} / \mathrm{g})$, kesukaan panelis terhadap warna serbuk 3,55 (netral/ biasa), warna minuman 3 (netral/ biasa), aroma minuman 2,65 (tidak menyukai), dan rasa minuman 2,85 (tidak suka).

Kata kunci : maltodekstrin, lama pengeringan, vitaminc, minuman instan
\end{abstract}




\section{PENDAHULUAN}

Produk pangan bubuk (instan) merupakan produk pangan yang berbentuk bubuk atau tepung, mudah larut dalam air panas atau dingin, tidak mengendap serta cepat dalam penyajian (Wasmun $d k k ., 2016$ ). Salah satu jenis tanaman yang dapat diolah menjadi minuman instan bubuk yaitu terong cepoka. Terong Cepoka (Solanum torvum) termasuk dari sekian banyak tanaman yang kurang peminatnya dalam hal budidaya. Dalam Warta Penelitian dan Pengembangan Tanaman Industri (2009) sebutan terong cepoka di beberapa daerah pun berbeda antara lain terong pipit, terong rimbang (Melayu), terong takokak (Jawa Barat) dan terong cepoka (Jawa Tengah). Budidaya terong cepoka masih jarang ditemukan dan cenderung tumbuh secara liar karena banyak masyarakat yang kurang mengetahui manfaat dari terong cepoka terutama manfaatnya dalam bidang kesehatan (obat). Pada dasarnya semua bagian dari terong cepoka mulai dari akar, daun, dan buah dapat diguanakan. Terong cepoka (Solanum torvum) terkenal sebagai tanaman obat tradisional yang dapat menyembuhkan beberapa penyakit antara lain penyakit lambung, bengkak, batuk kronis, bisul, menyembuhkan mata minus, dan menurunkan tekanan darah tinggi. Namun, kebanyakan masyarakat dalam mengkonsumsi terong cepoka hanya diolah menjadi sayuran (Pratiwi, 2012).

Kandungan kimia dari terong cepoka antara lain alkaloid steroid yaitu jenis solasodin $0,84 \%$. Solasodin terdapat pada buah terong cepoka yang masih hijau, jika sudah menguning solasodin pada terong cepoka akan berubah menjadi solasonin $0,1 \%$. Kandungan lain dari terong cepoka yaitu chlorogenin, sisologenenone, torvogenin, vitamin $\mathrm{A}, 4 \mathrm{~g}$ vitamin $\mathrm{C}$, neo chlorogenine, air 85,4 g, 2,4 g protein, $0,4 \mathrm{~g}$ lemak, 10,7 g karbohidrat, 6,1 g serat, 104 mg Ca, 70 mg P, dan 4,6 mg Fe (Balitbang Pertanian, 2015 dan Out et al., 2017).
Untuk menjaga kandungan gizi pada terong cepoka dibutuhkan pengolahan yang benar. Pada penelitian ini faktor yang digunakan adalah perbedaan persentase maltodekstrin dan lama pengeringan dengan menggunakan suhu $80^{\circ} \mathrm{C}$ (Putra $d k k$., 2013). Sedangkan untuk membantu dalam proses pengeringan minuman instan terong cepoka,maka dibutuhkan bahan pengisi untuk mempercepat proses pengeringan yaitu maltodekstrin. Maltodekstrin berfungsi untuk melapisi komponen flavor, memperbesar volume, mempercepat proses pengeringan, mencegah kerusakan bahan akibat panas, dan meningkatkan daya kelarutan (Yuliawati, 2015).

\section{METODE PENELITIAN \\ Rancangan Percobaan}

Rancangan percobaan yang digunakan adalah Rancangan Acak Kelompok (RAK) Faktorial yang terdiri dari 2 faktor yaitu komposisi maltodekstrin $(10 \%, 20 \%$, dan $30 \%)$ dan lama pengeringan (6 jam dan 7 jam), sehingga didapatkan 6 kombinasi perlakuan.

\section{Tempat dan Waktu Penelitian}

Penelitian dilaksanakan di Laboratorium Rekayasa Pangan Universitas Yudharta Pasuruan dan Laboratorium Uji Keamanan Pangan Universitas Brawijaya Malang. Penelitian dilaksanakan pada bulan Mei sampai Juli 2018.

\section{Bahan}

Bahan yang digunakan dalam pembuatan minuman serbuk instan terong cepoka adalah terong cepoka segar yang diperoleh dari desa Gondang kecamatan Tugu kabupaten Trenggalek, maltodekstrin (toko Deli sentosa Prima Jakarta Barat), dan air (Sumur). Sedangkan bahan yang digunakan untuk analisa adalah aquadest, kertas saring, dan larutan buffer, larutan biru metilen, asam askorbat, $\mathrm{NaOH}, \mathrm{FeSO} 4$, betadin, dan methanol.

\section{Tahap Pelaksanaan Kegiatan}

Adapun proses Pembuatan Sari Buah Terong Cepoka sebagai berikut: 
1. Persiapan Bahan

2. Penimbangan

3. Pencucian

4. Blanching

5. Penghancuran

6. Penambahan Air Hangat

7. Penyaringan.

Sedangkan proses Pembuatan Serbuk Minuman Instan Terong Cepoka sebagai berikut:

1. Pencampuran dengan maltodekstrin

2. Pengeringan

3. Pembubukan

4. Pengayakan

\section{Pengamatan}

Analisis yang dilakukan pada minuman serbuk instan terong cepoka meliputi analisis fisik kimia yaitu kecepatan larut, kadar air, dan kadar vitamin C. Sedangkan analisis organoleptik meliputi warna serbuk, warna minuman, rasa minuman, dan aroma minuman.

\section{Analisis Data}

Untuk melengkapai semua data yang dibutuhkan maka ada beberapa analisa yang akan digunakan dalam penelitian ini antara lain analisa data dilakukan secara ANOVA. Jika berbeda nyata, maka dilanjutkan dengan menggunakan uji Beda Nyata Terkecil (BNT), uji organoleptik menggunakan uji Friedman dan untuk mencari perlakuan terbaik menggunakan metode Indeks Efektifitas De Garmo (1984) yang dimodifikasi oleh Susrini (2003).

\section{HASIL DAN PEMBAHASAN}

Hasil Analisa Fisikokimia Minuman Serbuk Instan Terong Cepoka

Hasil analisis sidik ragam menunjukkan bahwa adanya pengaruh yang sangat nyata antara kombinasi perlakuan (BNT 5\%) terhadap kadar vitamin $\mathrm{C}$, KA, dan Kecepatan Larut minuman serbuk instan terong cepoka yang dihasilkan. Rata-rata kadar vitamin $\mathrm{C}$ pada berbagai kombinasi perlakuan ditunjukkan pada tebel 1 .

Tabel 1. Hasil Analisa Fisikokimia Minuman Serbuk Instan Terong Cepoka

\begin{tabular}{|c|c|c|c|c|c|c|}
\hline \multirow{3}{*}{$\begin{array}{c}\text { Perlakua } \\
\text { n }\end{array}$} & \multicolumn{6}{|c|}{ Analisa } \\
\hline & \multicolumn{2}{|c|}{ Vit. C } & \multicolumn{2}{|c|}{ KA } & \multicolumn{2}{|c|}{ Kec. Larut } \\
\hline & Rerata & Notasi & Rerata & Notasi & Rerata & Notasi \\
\hline M1P1 & 7,02 & $\mathrm{a}$ & 7,41 & $\mathrm{a}$ & 1,230 & $\mathrm{a}$ \\
\hline M1P2 & 7,05 & $\mathrm{a}$ & 7,89 & $\mathrm{~b}$ & 1,223 & $\mathrm{a}$ \\
\hline M2P1 & 14,31 & $\mathrm{~b}$ & 8,10 & $\mathrm{bc}$ & 1,126 & $\mathrm{a}$ \\
\hline M2P2 & 14,34 & $\mathrm{~b}$ & 8,32 & $\mathrm{~cd}$ & 0,620 & $\mathrm{~b}$ \\
\hline M3P1 & 24,85 & c & 8,40 & de & 0,403 & $\mathrm{c}$ \\
\hline M3P2 & 28,75 & $\mathrm{~d}$ & 8,58 & $\mathrm{e}$ & 0,340 & $\mathrm{c}$ \\
\hline BNT $(5 \%)$ & \multicolumn{2}{|c|}{0,26} & \multicolumn{2}{|c|}{0,254} & \multicolumn{2}{|c|}{0,22} \\
\hline
\end{tabular}

Vitamin C merupakan salah satu zat gizi yang berfungsi sebagai antioksidan dan mampu mencegah radikal bebas (Fiana $d k k$.,
2016). Histogram rata-rata kadar Vitamin C pada berbagai kombinasi perlakuan disajikan pada gambar 1 . 


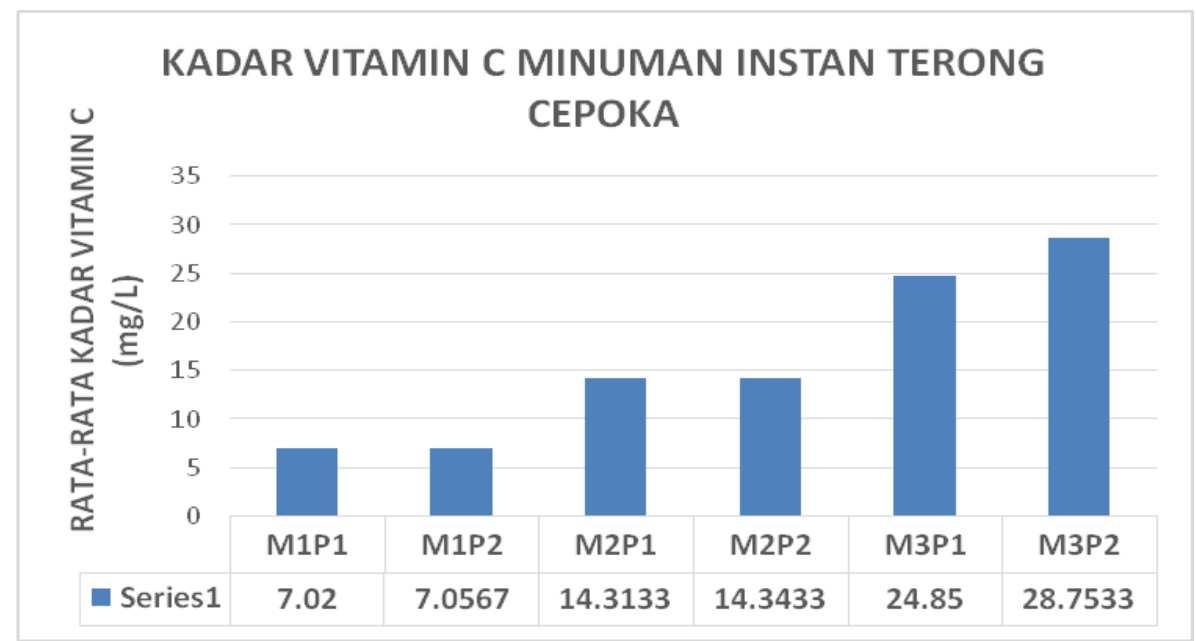

Keterangan :

Gambar 1. Grafik Vitamin C Minuman Instan Terong Cepoka

M1P1 = penambahan maltodekstrin 10\% dan lama pengeringan 6 jam, M1P2 = penambahan maltodekstrin $10 \%$ dan lama pengeringan 7 jam, M2P1 = penambahan maltodekstrin $20 \%$ dan lama pengeringan 6 jam, M2P2 = penambahan maltodekstrin 20\% dan lama pengeringan 7 jam, M3P1 = penambahan maltodekstrin 30\% dan lama pengeringan 6 jam, M3P2 = penambahan maltodekstrin $30 \%$ dan lama pengeringan 7 jam

Gambar 1. menunjukkan bahwa pengaruh persentase maltodekstrin dan lama pengeringan terhadap kadar vitamin $\mathrm{C}$ meningkat. Penambahan maltodekstrin dengan persentase $30 \%$ memiliki Semakin kemampuan yang tinggi dalam mempertahankan kadar vitamin $\mathrm{C}$ yang terkandung di dalam bahan baku jika dibandingkan dengan penambahan maltoedkstrin $10 \%$ dan $20 \%$. Hal ini dikarenakan kemampuan maltodekstrin dalam melindungi bahan yang disalutnya (Fiana dkk., 2016). Semakin banyak maltodekstrin yang ditambahkan, maka maltodekstrin akan semakin kuat untuk mengikat vitamin $\mathrm{C}$.

Tinggi kadar air dalam suatu produk pangan, maka akan semakin rentan rusak dan memiliki daya simpan yang relativ tidak lama (Amanto $d k k$., 2015). Histogram ratarata kadar air pada berbagai kombinasi perlakuan disajikan pada gambar 2 .

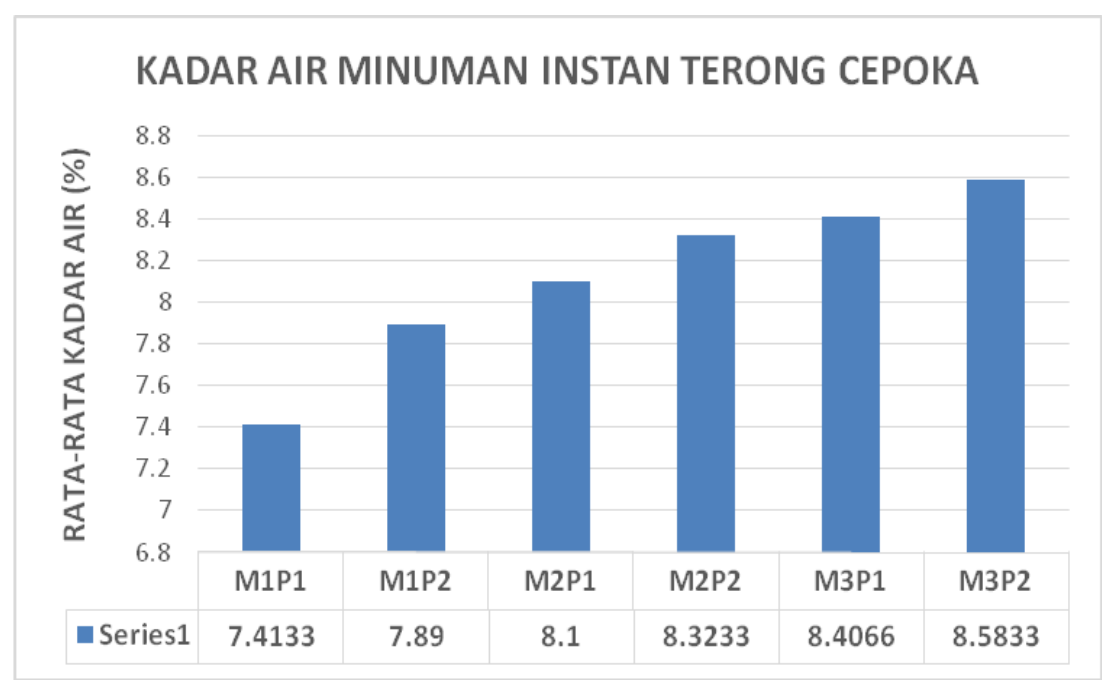

Gambar 2. Grafik Kadar Air Minuman Instan Terong Cepoka 
Keterangan :

M1P1 = penambahan maltodekstrin $10 \%$ dan lama pengeringan 6 jam, M1P2 $=$ penambahan maltodekstrin $10 \%$ dan lama pengeringan 7 jam, M2P1 = penambahan maltodekstrin $20 \%$ dan lama pengeringan 6 jam, M2P2 = penambahan maltodekstrin $20 \%$ dan lama pengeringan 7 jam, M3P1 = penambahan maltodekstrin 30\% dan lama pengeringan 6 jam, M3P2 = penambahan maltodekstrin $30 \%$ dan lama pengeringan 7 jam

Hasil analisis sidik ragam yang telah dilakukan menunjukkan bahwa perlakuan konsentrasi maltodekstrin dan lama pengeringan berbeda dengan literatur, hal ini disebabkan adanya proporsi penambahan maltodekstrin yang tinggi, kemasan penyimpanan yang berupa plastik zipper, dan lamanya penyimpanan bahan yang tidak langsung diuji diduga menyebabkan jumlah gugus hidroksilnya pun semakin banyak sehingga dapat mengikat air dari lingkungan lebih banyak. Dengan demikian, banyaknya proporsi maltodekstrin dan semakin lamanya penyimpanan maka readsorpsi uap air semakin bertambah dan mengakibatkan kadar air dalam bahan ikut bertambah (Rokilah $d k k$., 2018., dan Yuliawaty $d k k$., 2015)

Analisis kelarutan dilakukan untuk mengetahui berapa kecepatan yang dibutuhkan oleh suatu produk (serbuk minuman instan) dalam air ketika akan dikonsumsi. Semakin cepat kecepatan larut suatu produk maka mutu produk yang dihasilkan akan semakin baik (Alfonsius $d k k ., 2015)$. Histogram rata-rata kecepatan larut pada berbagai kombinasi perlakuan disajikan pada Gambar 3.

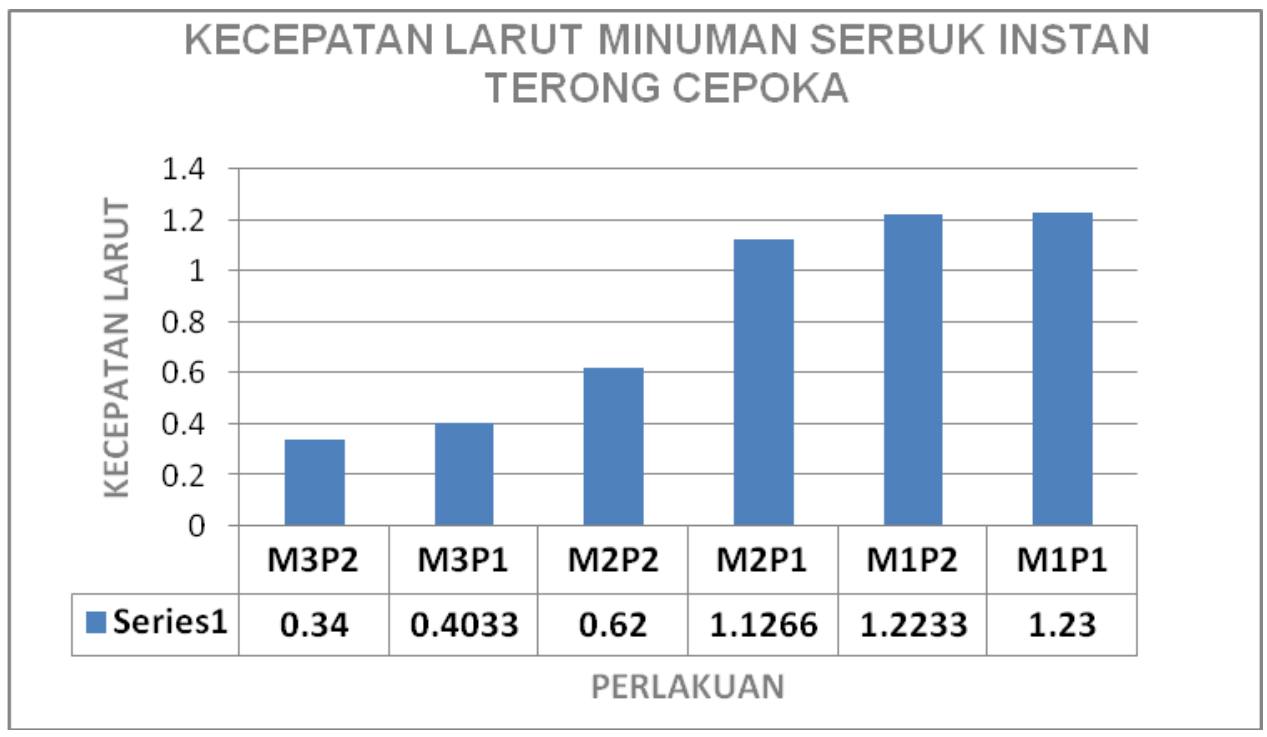

Gambar 3. Grafik Kecepatan Larut Minuman Serbuk Instan Terong Cepoka

Keterangan :

M1P1 = penambahan maltodekstrin $10 \%$ dan lama pengeringan 6 jam, M1P2 $=$ penambahan maltodekstrin $10 \%$ dan lama pengeringan 7 jam, M2P1 = penambahan maltodekstrin $20 \%$ dan lama pengeringan 6 jam, M2P2 = penambahan maltodekstrin $20 \%$ dan lama pengeringan 7 jam, M3P1 = penambahan maltodekstrin 30\% dan lama pengeringan 6 jam, M3P2 = penambahan maltodekstrin $30 \%$ dan lama pengeringan 7 jam

Maltodekstrin merupakan bahan pengisi yang memiliki tingkat kelarutan tinggi, hal ini karena sifat dari maltodekstrin yaitu larut dalam air dan memiliki proses dispersi yang cepat (Ramadhani, 2016). Hasil tersebut menunjukkan bahwa variasi maltodekstrin 
memberikan pengaruh terhadap kecepatan larut minuman serbuk instan terong cepoka. Semakin tinggi kecepatan larut suatu serbuk menjadi sebuah minuman maka akan semakin baik karena waktu yang dibutuhkan akan semakin singkat. Hal ini disebabkan luasnya permukaan serbuk yang meningkat dapat menyebabkan serbuk menjadi lebih cepat larut ketika bertemu dengan air dalam penyajian.

\section{Hasil Analisa Uji Organoleptik Minuman Serbuk Instan Terong Cepoka Warna Serbuk}

Warna merupakan parameter pertama yang dilihat oleh konsumen sehingga dapat menentukan tingkat penerimaan terhadap suatu produk (Paramita, 2014). Grafik tingkat kesukaan panelis terhadap warna serbuk instan terong cepoka dapat dilihat pa da gambar 4 .

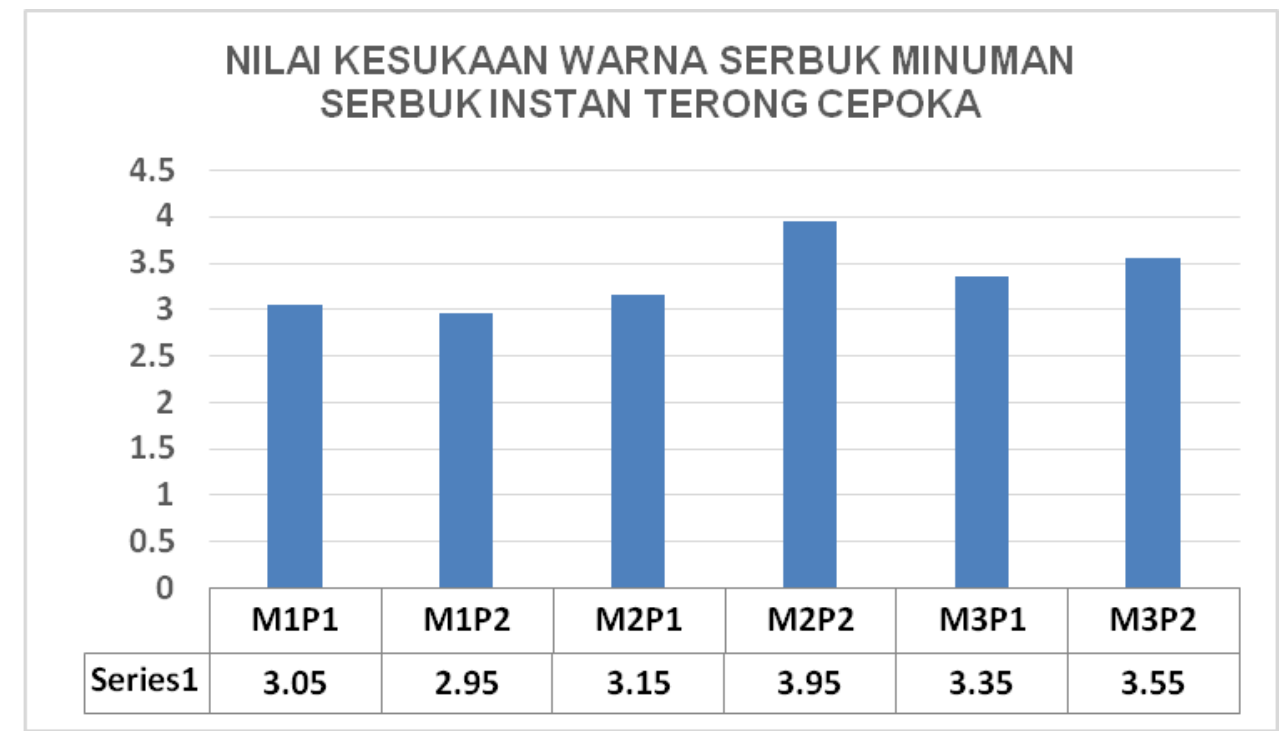

Gambar 4. Grafik Nilai Kesukaan Aroma Serbuk Minuman Instan Terong Cepoka

Keterangan :

M1P1 = penambahan maltodekstrin $10 \%$ dan lama pengeringan 6 jam, M1P2 $=$ penambahan maltodekstrin $10 \%$ dan lama pengeringan 7 jam, M2P1 = penambahan maltodekstrin $20 \%$ dan lama pengeringan 6 jam, M2P2 = penambahan maltodekstrin 20\% dan lama pengeringan 7 jam, M3P1 = penambahan maltodekstrin 30\% dan lama pengeringan 6 jam, M3P2 = penambahan maltodekstrin $30 \%$ dan lama pengeringan 7 jam

Tingkat kesukaan terendah terhadap warna serbuk instan terong cepoka adalah pada perlakuan M1P2 yaitu dengan konsentrasi maltodekstrin $10 \%$ dan lama pengeringan 7 jam. Hal ini dikarenakan rendahnya konsentrasi maltodekstrin yang mengakibatkan warna serbuk tidak mengalami perubahan warna dari warna larutan asalnya. Maltodekstrin dapat digunakan dalam aplikasi dengan temperatur tinggi, karena memiliki kandungan gula pereduksi yang rendah sehingga tidak membentuk zat warna pada reaksi pencoklatan (browning) (Ramadhani, 2016). Selain itu, penambahan maltodekstrin menyebabkan warna serbuk cenderung semakin putih dan sedikit kecoklatan. Semakin tinggi maltodekstrin maka warna yang dihasilkan dari sebuah produk akan semakin jauh dari warna aslinya (Putra, 2013). Suhu pengeringan yang digunakan dalam pembuatan minuman serbuk buah instan antara suhu $50-80^{\circ} \mathrm{C}$ dengan lama pengeringan dalam oven adalah 6-18 jam (Yuliawaty, 2015). 
Warna serbuk dengan tingkat kesukaan paling tinggi adalah warna serbuk instan terong cepoka dengan nilai 3,95 pada perlakuan M2P2. Pada perlakuan M2P2 ini konsentrasi maltodekstrin $20 \%$ dan lama pengeringan 7 jam. Penggunaan maltodekstrin sebanyak 20\% dengan lama pengeringan yang panjang menghasilkan warna serbuk yang coklat. Pada sample dengan kode M3P1 dan M3P2 menggunakan maltodekstrin 30\% membuat panelis kurang begitu menyukai karena warna yang ditampilkan kurang menarik yaitu berwarna coklat pudar.

\section{Warna Minuman}

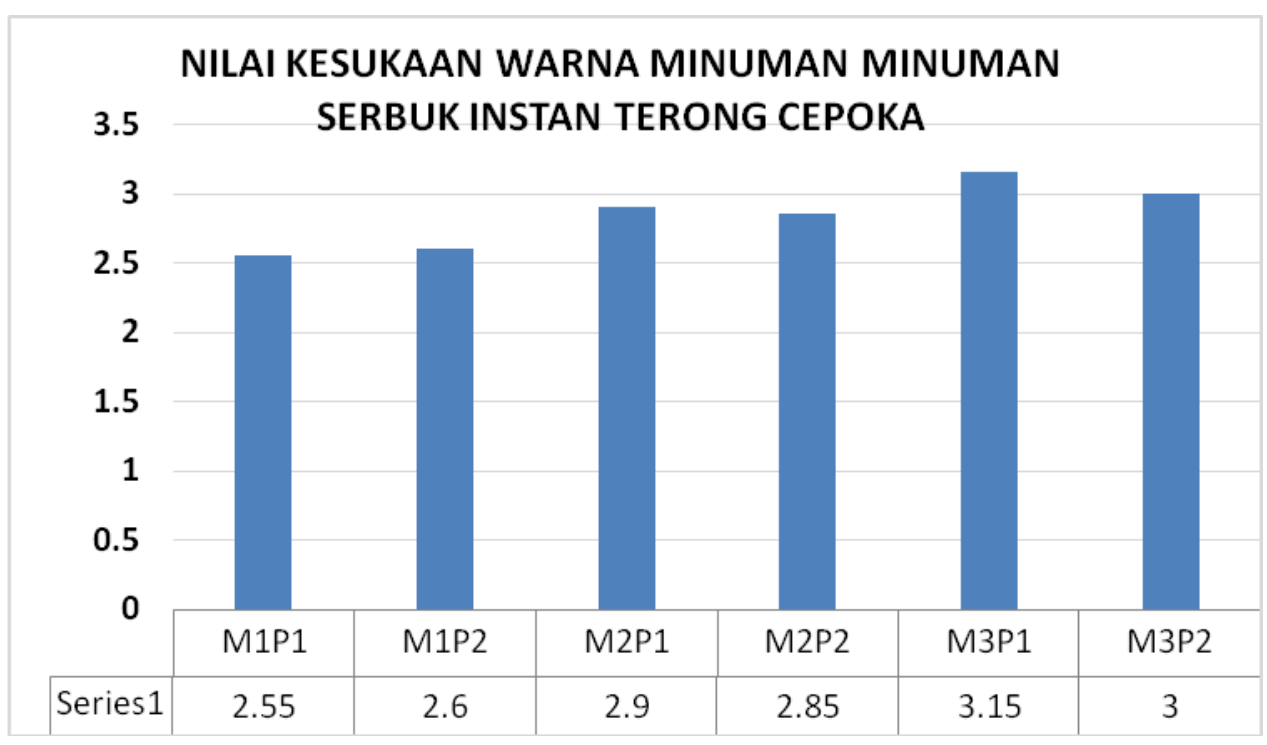

Gambar 5. Grafik Nilai kesukaan Warna Minuman Serbuk Instan Terong Cepoka

Keterangan :

M1P1 = penambahan maltodekstrin 10\% dan lama pengeringan 6 jam, M1P2 = penambahan maltodekstrin $10 \%$ dan lama pengeringan 7 jam, M2P1 = penambahan maltodekstrin $20 \%$ dan lama pengeringan 6 jam, M2P2 = penambahan maltodekstrin $20 \%$ dan lama pengeringan 7 jam, M3P1 = penambahan maltodekstrin 30\% dan lama pengeringan 6 jam, M3P2 = penambahan maltodekstrin $30 \%$ dan lama pengeringan 7 jam

Tingkat kesukaan terendah warna minuman dari serbuk instan terong cepoka berada pada sample M1P1 dengan konsentrasi maltodekstrin $10 \%$ dan lama pengeringan 6 jam. Hal ini dikarenakan rendahnya konsentrasi maltodekstrin dan singkatnya pengeringan membuat warna minuman menjadi sangat gelap (kehitaman). Warna minuman dengan tingkat kesukaan paling tinggi adalah minuman serbuk instan terong cepoka dengan nilai konsentrasi matodekstrin paling tinggi 30\% dengan lama pengeringan 6 jam. Penggunaan maltodekstrin yang tinggi menghasilkan warna minuman yang lebih terang. Semakin tinggi maltodekstrin maka warna yang dihasilkan dari sebuah produk akan semakin jauh dari warna aslinya (Putra, 2013).

\section{Aroma Minuman}

Aroma adalah bau yang timbul dari rangsangan kimia yang tercium oleh syarafsyaraf olfaktori yang berada dalam rongga hidung (Aretzy, 2018). Grafik tingkat kesukaan panelis terhadap aroma minuman serbuk instan terong cepoka dapat dilihat pada gambar 6 . 


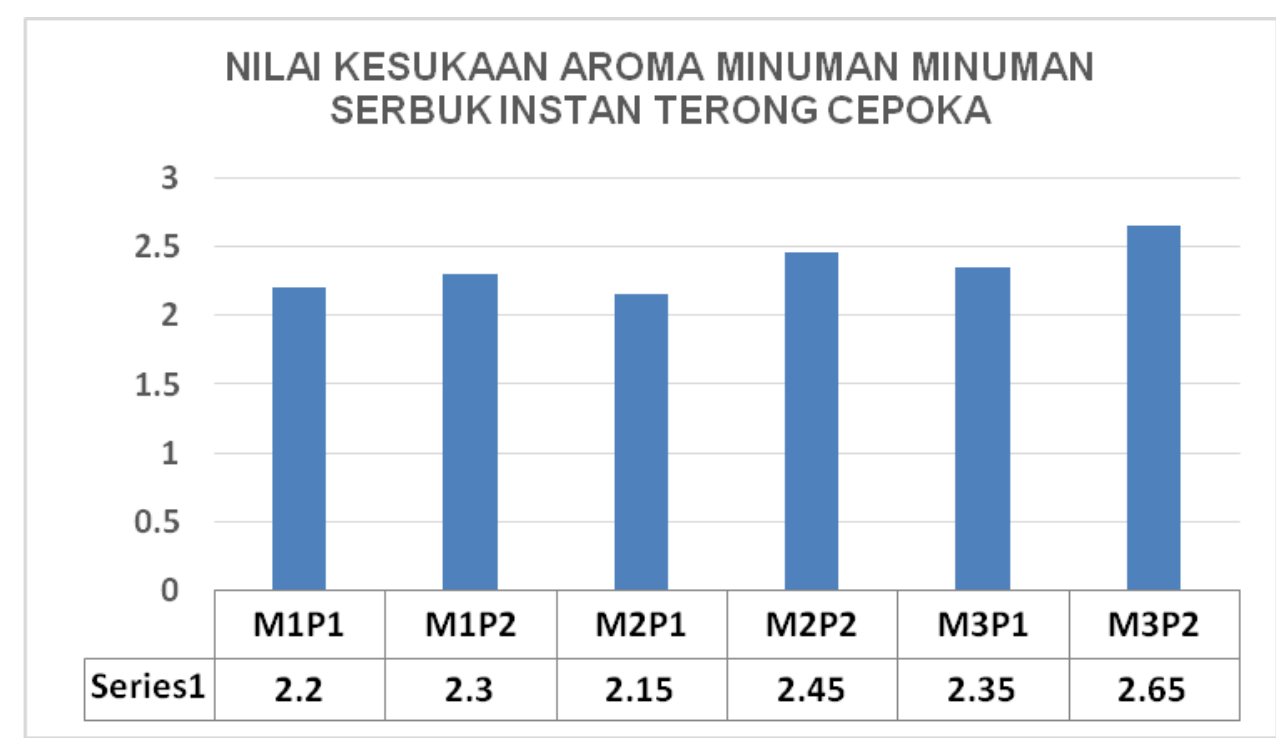

Gambar 6. Grafik Nilai Aroma minuman Serbuk Instan Terong Cepoka Keterangan :

M1P1 = penambahan maltodekstrin 10\% dan lama pengeringan 6 jam, M1P2 = penambahan maltodekstrin $10 \%$ dan lama pengeringan 7 jam, M2P1 = penambahan maltodekstrin $20 \%$ dan lama pengeringan 6 jam, M2P2 = penambahan maltodekstrin $20 \%$ dan lama pengeringan 7 jam, M3P1 = penambahan maltodekstrin 30\% dan lama pengeringan 6 jam, M3P2 = penambahan maltodekstrin $30 \%$ dan lama pengeringan 7 jam

Tingkat kesukaan terendah oleh panelis diberikan pada minuman serbuk instan terong cepoka dengan konsentrasi maltodekstrin 20\% dan lama pengeringan 6 jam. Hal ini karena konsentrasi maltodekstrin yang rendah dan singkatnya pengeringan mengakibatkan aroma minuman instan terong cepoka menjadi tetap lengur.

Tingkat kesukaan tertinggi oleh panelis diberikan pada minuman serbuk instan terong cepoka dengan konsentrasi maltodekstrin $30 \%$ dan lama pengeringan 7 jam. Konsentrasi maltodekstrin dan suhu pengeringan berpengaruh terhadap aroma minuman serbuk instan terong cepoka, konsentrasi maltodekstrin yang tinggi dapat melindungi senyawa atsiri dalam terong cepoka dan suhu pengeringan yang tinggi, walaupun perlindungan dari maltodekstrin tinggi namun suhu yang digunakan tinggi dan lama maka mengakibatkan aroma lengur pada minuman instan terong cepoka menjadi berkurang (Paramita, 2015).

\section{Rasa Minuman}

Rasa merupakan parameter yang paling penting dalam sebuah produk karena rasa menentukan diterima dan tidak diterimanya sebuah produk. Grafik tingkat kesukaan panelis terhadap rasa minuman instan terong cepoka dapat dilihat pada gambar 7 . 


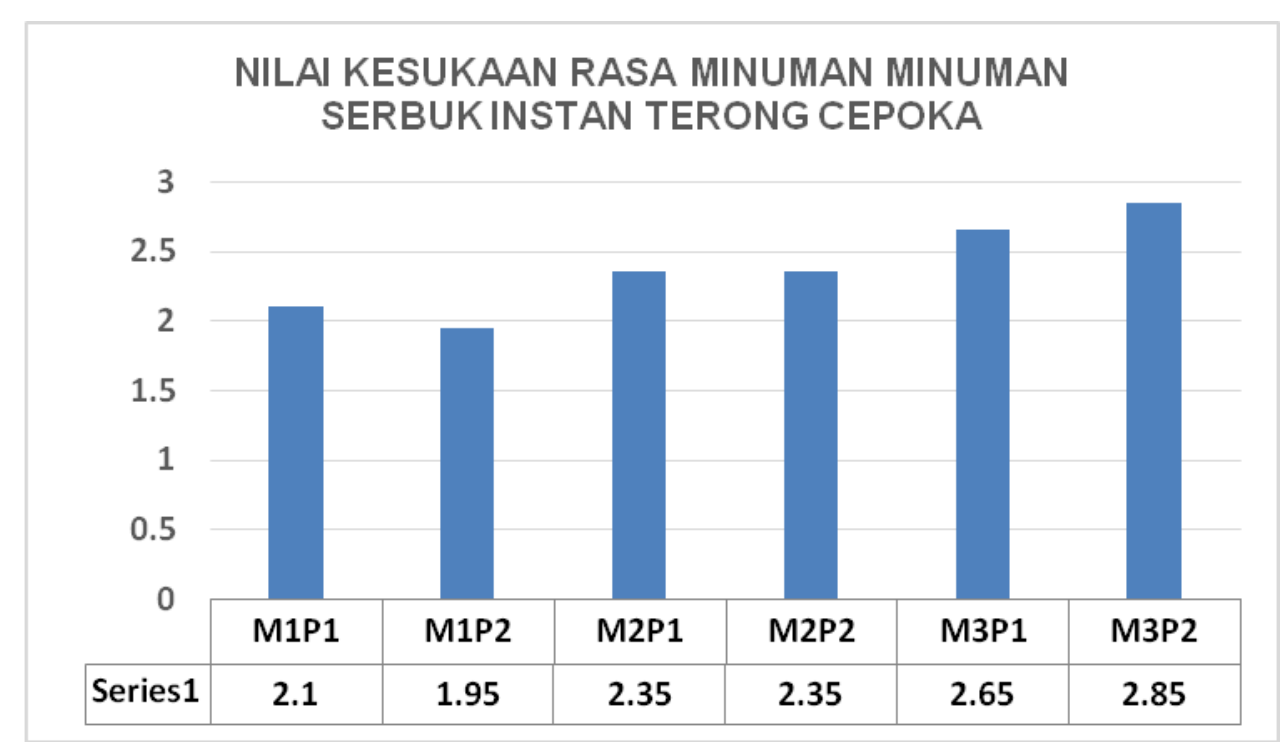

Keterangan :

Gambar 7. Grafik Nilai Rasa minuman Serbuk Instan Terong Cepoka

M1P1 = penambahan maltodekstrin $10 \%$ dan lama pengeringan 6 jam, M1P2 $=$ penambahan maltodekstrin $10 \%$ dan lama pengeringan 7 jam, M2P1 = penambahan maltodekstrin $20 \%$ dan lama pengeringan 6 jam, M2P2 = penambahan maltodekstrin $20 \%$ dan lama pengeringan 7 jam, M3P1 = penambahan maltodekstrin 30\% dan lama pengeringan 6 jam, M3P2 = penambahan maltodekstrin $30 \%$ dan lama pengeringan 7 jam

Tingkat kesukaan terendah oleh panelis diberikan pada minuman serbuk instan terong cepoka dengan konsentrasi maltodekstrin $10 \%$ dan lama pengeringan 7 jam. Hal ini karena konsentrasi maltodekstrin dan lama pengeringan mengakibatkan rasa minuman instan terong cepoka masih tetap pahit walaupun kandungan saponin yang ada pada terong cepoka sudah berkurang pada saat blanching. Saponin merupakan steroid atau glukosida triterpenoid yang terikat pada karbohidrat. Saponin adalah jenis senyawa yang dapat menyebabkan rasa pahit pada bahan nabati, memiliki karakteristik dalam bentuk busa dan dapat larut dalam air. Beberapa senyawa antinutrisi seperti asam oksalat, tanin, HCN dan saponin yang terdapat dalam buah dan sayur dapat dikurangi dengan cara blanching, terutama ketika proses menggunakan air matang (Indriasari $d k k ., 2016$ ).

Tingkat kesukaan tertinggi oleh panelis diberikan pada minuman serbuk instan terong cepoka dengan konsentrasi maltodekstrin $30 \%$ dan lama pengeringan 7

jam. Hal ini karena konsentrasi maltodekstrin dan lama pengeringan mengakibatkan rasa pahit pada minuman instan terong cepoka menjadi berkurang. Dalam industri makanan dan minuman maltodekstrin digunakan sebagai pensuplay bahan pemanis nutritif dengan derajat kemanisan rendah namun berkalori (Husniati, 2009).

\section{Pemilihan Perlakuan Terbaik Dengan Metode Indeks Efektifitas}

Penentuan perlakuan terbaik pada minuman serbuk instan terong cepoka dilakukan dengan menggunakan metode indeks efektifitas (De Garmo, 1984) yang dimodifikasi oleh Susrini (2003). Metode ini dilakukan pada parameter kimiawi meliputi uji vitamin $\mathrm{C}$, kadar air, kecepatan larut, serta uji fisik yang meliputi warna serbuk, warna minuman, aroma minuman, dan rasa minuman.

Hasil perhitungan menunjukkan perlakuan terbaik terdapat pada perlakuan M3P2 (maltodekstrin 30\% dan pengeringan 7 jam) dengan ketentuan fisiko kimia kadar 
air (8,58\%), Kecepatan Larut (0,34s), Vitamin C $(28,75 \mathrm{mg} / \mathrm{g})$, warna serbuk 3,55 (netral/biasa), warna minuman 3,00 (netral/biasa), aroma minuman 2,65 (tidak menyukai), dan rasa minuman 2,85 (tidak menyukai).

Tabel 2. Indeks Efektifitas Fisikokimia dan Organoleptik

\begin{tabular}{ccl}
\hline No. & \multicolumn{1}{c}{ Perlakuan } & \multicolumn{1}{c}{ Rata-rata } \\
\hline 1 & M1P1 (maltodekstrin 10\% dan pengeringan 6 jam) & 0.113 \\
2 & M1P2 (maltodekstrin 10\% dan pengeringan 7 jam) & 0.190 \\
3 & M2P1 (maltodekstrin 20\% dan pengeringan 6 jam) & 0.285 \\
4 & M2P2 (maltodekstrin 20\% dan pengeringan 7 jam) & $0.444^{* 3}$ \\
5 & M3P1 (maltodekstrin 30\% dan pengeringan 6 jam) & $0.502 *^{2}$ \\
6 & M3P2 (maltodekstrin 30\% dan pengeringan 7 jam) & $0.613^{* 1}$ \\
\hline
\end{tabular}

Keterangan $:{ }^{*}$ : terbaik $1,{ }^{* 2}$ : terbaik $2,{ }^{* 3}$ : terbaik 3

\section{KESIMPULAN}

Berdasarkan hasil penelitian dan pembahasan yang ada dapat disimpulkan sebagai berikut:

1. Analisa Vitamin $\mathrm{C}$ terbaik pada kombinasi perlakuan M3P2 (maltodekstrin $30 \%$ dan lama pemanasan 7 jam) dengan nilai 28, 75mg/g. Analisa Kadar Air terbaik perlakuan pada kombinasi perlakuan M3P2 (maltodekstrin 30\% dan lama pemanasan 7 jam) dengan nilai $8,58 \%$. Analisa Kecepatan larut terbaik pada kombinasi perlakuan M3P2 (maltodekstrin $30 \%$ dan lama pemanasan 7 jam) dengan nilai $0,34 \mathrm{~s}$.

2. Berdasarkan uji Organoleptik, perlakuan terbaik terhadap warna serbuk didapatkan pada variasi perlakuan M2P2 (maltodekstrin 20\% dan lama pemanasan 7 jam) dengan nilai 3,95 (netral/biasa), warna minuman didapatkan pada variasi perlakuan M3P1 (maltodekstrin 30\% dan lama pemanasan 7 jam) dengan nilai 3,15 (netral/biasa), aroma didapatkan pada variasi perlakuan M3P2 (maltodekstrin $30 \%$ dan lama pemanasan 7 jam) dengan nilai 2,65 (tidak menyukai) dan rasa didapatkan pada variasi perlakuan M3P2 ( (maltodekstrin 30\% dan lama pemanasan $7 \mathrm{jam}$ ) dengan nilai 2,85 (tidak menyukai).

3. Perlakuan terbaik adalah M3P2 (maltodekstrin $30 \%$ dan lama pemanasan 7 jam) dengan karakteristik sebagai berikut kadar air (8,58\%), Kecepatan Larut $(0,34 \mathrm{~s})$, Vitamin C $(28,75 \mathrm{mg} / \mathrm{g})$, warna serbuk 3,55 (netral/biasa), warna minuman 3,00 (netral/biasa), aroma minuman 2,65 (tidak menyukai), dan rasa minuman 2,85 (tidak menyukai).

\section{Saran}

Saran yang dapat disampaikan berdasarkan penelitian yang telah dilakukan adalah sebagai berikut:

1. Penelitian lanjutan mengenai pengaruh persentase maltodekstrin dan suhu pengeringan terhadap kandungan vitamin $\mathrm{C}$ minuman serbuk instan terong cepoka (Solanum torvum)

2. Penelitian lanjut mengenai pengaruh persentase maltodekstrin dan lama pencampuran terhadap kandungan vitamin $\mathrm{C}$ minuman serbuk instan terong cepoka (Solanum torvum)

\section{DAFTAR PUSTAKA}

Alfonsius., Pranata, S., dan Purwijantiningsih, E. (2015). Kualitas Minuman Serbuk Instan Kayu Secang (Caesalpinia sappan L) Dengan Variasi Maltodekstrin. Jurnal Universitas Atma Jaya: Yogyakarta

Amanto, B. S., Siswanti., dan Atmaja, A. (2015). Kinetika Pengeringan Temu Giring (Curcuma heyneana Valeton \& 
van Zijp) Menggunakan Kabinet Dryer Dengan Perlakuan Pendahuluan Blanching. Jurnal Teknologi Hasil Pertanian, VIII (2), 107- 114

Aretzy, A., Ansarullah, dan Wahab, D. (2018). Pengembangan Minuman Instan Dari Limbah Biji Buah Alpukat (Persea americana Mill) Dengan Pengaruh Penambahan Maltodekstrin. Jurnal Sains dan Teknologi Pangan, 3 (1), 1027- 1035

Fiana, R. M., Murtius, W. S., dan Asben, A. (2016). Pengaruh Konsentrasi Maltodekstrin Terhadap Mutu Minuman Instan dari Teh Kombucha. Jurnal Teknologi Pertanian Andalas, $20(2), 1-8$

Husniati. (2009). Studi Karekterisasi Sifat Fungsi Maltodekstrin dari Pati Singkong. Jurnal Riset Industri, 3 (2), 133- 138

Indriasari, $\quad$ Y., Wignyanto., and Kumalaningsih, S. (2016). Effect of Blanching on Saponin and Nutritional Content of Moringa Leaves Extract. Journal of Food Research, 5 (3), 5560

Paramita, I. A. M. I., Mulyani, S., dan Hartiati, A. (2014). Pengaruh Konsentrasi Maltodekstrin Dan Suhu Pengeringan Terhadap Karakteristik Bubuk Minuman Sinom. Artikel Portal Garuda, 1-11

Putra, S. D. R., Ekawati, L. M. (2013). Kualitas Minuman Serbuk Instan Kulit Buah Manggis (Garcinia mangostana Linn) Dengan Variasi Maltodekstrin Dan Suhu Pemanasan. Jurnal UAJY, 1- 15

Ramadhani, D. (2016). Pengaruh Konsentrasi Maltodekstrin dan Putih Telur Terhadap Karakteristik Minuman Serbuk Buah Naga Merah
(Hylocereus polyrhizus). Artikel Universitas Pasundan, 1- 19

Rokilah, Prarudiyanto, A., dan Werdiningsih, W. (2018). Pengaruh Kombinasi Kemasan dan Masa Simpan Terhadap Beberapa Komponen Mutu Bumbu Plencingan Instan. Jurnal Ilmiah rekayasa Penelitian dan Biosistem, 6 (1), 60-68

Siroit, N. (2009). Terong Cepoka (Solonum torvum) Herba yang Berkhasiat Sebagai Obat. Warta Penelitian dan Pengembangan Tanaman Industri, 15 (3), 10-12

Wasmun, H., Rahim, A., dan Hutomo, G. S. (2016). Pembuatan Minuman Instan Fungsional Dari Bioaktif Pod Husk Kakao. E-jurnal Agrotekbis, 4 (6), 650- 658

Yuliawaty, S. T., dan Susanto, W. H. (2015). Pengaruh Lama Pengeringan dan Konsentrasi Maltodekstrin Terhadap Karakteristik Fisik Kimia dan Organoleptik Minuman Instan Daun Mengkudu (Morinda citrifolia L). Jurnal Pangan dan Agroindustri, 3 (1), 41-52 